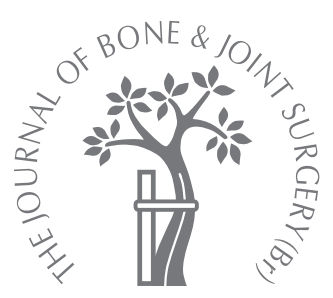

M. Ryzewicz, S. J. Morgan, E. Linford, J. I. Thwing, G. V. P. de Resende, W. R. Smith

From Denver Health Medical Center, Denver, United States

M. Ryzewicz, MD, Orthopaedic Surgeon Department of Orthopaedic Surgery

Bay Area Medical Center, 3117 Shore Drive, Marinette, Wisconsin 54143, USA.

= S. J. Morgan, MD, FACS, Associate Professor

E. Linford, MS, Medical

Student

W. R. Smith, MD, Professor Department of Orthopaedic

Surgery

Denver Health Medical Center University of Colorado Schoo of Medicine, 777 Bannock

Street, Denver, Colorado 80204 USA.

ㄷ. J. Thwing, MD, Resident Physician

4770 Buford Highway MSF-22, Atlanta, Georgia 30341, USA.

G. V. P. de Resende, MD, Orthopaedic Surgeon Department of Orthopaedic Surgery

Hospital RIO-Laranjeiras, Rua das Laranjeiras 72, Rio de Janeiro, Rio de Janeiro 22230070, Brazil.

Correspondence should be sent to Dr M. Ryzewicz; e-mail: Mark_Ryzewicz@hotmail.com

(C)2009 British Editorial Society of Bone and Joint Surgery doi:10.1302/0301-620X.91B4. $21399 \$ 2.00$

$J$ Bone Joint Surg $[\mathrm{Br}]$ 2009;91-B:522-9.

Received 13 June 2008

Accepted after revision 15 January 2009

\title{
Central bone grafting for nonunion of fractures of the tibia
}

\author{
A RETROSPECTIVE SERIES
}

Nonunion of the tibia associated with bone loss, previous infection, obliteration of the intramedullary canal or located in the distal metaphysis poses a challenge to the surgeon and significant morbidity to patients. We retrospectively reviewed the records of 24 patients who were treated by central bone grafting and compared them to those of 20 who were treated with a traditional posterolateral graft. Central bone grafting entails a lateral approach, anterior to the fibula and interosseous membrane which is used to create a central space filled with cancellous iliac crest autograft. Upon consolidation, a tibiofibular synostosis is formed that is strong enough for weight-bearing. This procedure has advantages over other methods of treatment for selected nonunions.

Of the 24 patients with central bone grafting, 23 went on to radiographic and clinical union without further intervention. All healed within a mean of 20 weeks (10 to 48 ). No further bone grafts were required, and few complications were encountered. These results were comparable to those of the 20 patients who underwent posterolateral bone grafting who united at a mean of 31.3 weeks (16 to 60) but one of whom required below-knee amputation for intractable sepsis.

Central bone grafting is a safe and effective treatment for difficult nonunions of the tibia.

Patients with delayed or nonunion of a fracture of the tibia may represent with a broad spectrum of clinical entities. Infection, the softtissue injury, bone loss, malalignment of the limb and patient morbidity make each nonunion unique. No one method of treatment is appropriate for every case.

Various methods of treatment have been described for nonunions, including reamed exchange intramedullary nailing, dynamisation, compression plating, percutaneous injection of bone marrow, ultrasound and functional bracing. It has been reported that nonunions with infection, bone loss or both represent a more complex problem and are better managed by posterolateral bone grafting, transfer of the fibula, bone transport, or sometimes amputation. ${ }^{1}$ A thorough evaluation of the patient will determine which method is appropriate.

Central bone grafting is an operative technique which to our knowledge has been described in the literature only once. ${ }^{2}$ A lateral approach, anterior to the fibula, is used to create a central compartment. Fresh autologous cancellous bone graft is then placed to achieve a tibiofibular synostosis above, at, and below the level of the nonunion. The central bone mass and the fibula consolidate into a tubular bone which is strong enough for weight-bearing.

This procedure has important advantages in treating complex nonunions of the tibia with associated bone loss or a history of infection. The relative simplicity of the technique, the positioning of the patient supine, and protection of the posterior neurovascular bundle may make this technique preferable to posterolateral bone grafting, bone transport or the use of a microvascular free fibula or rib graft.

\section{Patients and Methods}

This was a retrospective comparative study. The radiographs and clinical notes for all patients who had a nonunion of the tibia treated at our institution with either a posterolateral or a central bone graft between October 1998 and January 2007 were retrospectively reviewed. The initial injury was classified by its location in the proximal, middle or distal thirds of the tibia, and whether it was closed, or when open, by its Gustilo-Anderson grade. ${ }^{3,4}$ The date and details of the initial treatment method, and the number and type of 


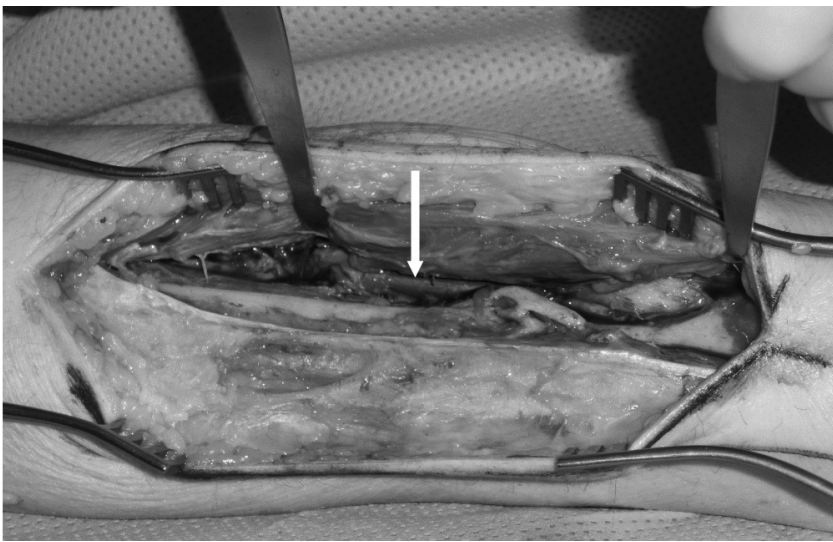

Fig. 1

The approach for central bone grafting has been performed and the segmental gap, shown here spanned by an intramedullary nail (arrow), is exposed and ready for placement of the cancellous autograft.

operations performed prior to the placement of a bone graft, were recorded. The peri-operative complications, additional operations required to achieve healing and the time to union were compared for the two techniques. Bone grafting performed on docking sites or regenerate associated with bone transport were excluded.

Infection was diagnosed if there had been a positive culture from bone during the course of treatment. If the patient had then received treatment that resulted in a normal erythrocyte sedimentation rate (ESR), C-reactive protein (CRP), resolution of draining sinuses and a negative culture from bone at the time of grafting, the infection was deemed 'adequately treated'. Active infection was indicated by the presence of draining sinuses or pus at the site of nonunion. If there was no gross evidence of infection but intraoperative cultures were positive, the infection was termed 'quiescent'.

A segmental bony defect was defined as showing no radiographic evidence of contact between the bone ends on either side of the nonunion on two orthogonal views. If a gap was present, it was measured from the point at which at least $50 \%$ of the diameter of the bone was present in the proximal fragment to the corresponding point on the distal fragment on a radiograph immediately preceding placement of the bone graft.

Each operation was performed by one of two fellowship-trained orthopaedic traumatologists (SJM, WRS) experienced in the treatment of nonunions of the tibia on fractures which, it was considered, would not progress to union without intervention, and were not amenable to a simpler treatment. Atrophic nonunions with a history of infection, segmental bone loss of $2 \mathrm{~cm}$ or more, obliteration of the intramedullary canal preventing placement of an intramedullary nail, or in the distal metaphysis were considered to be appropriate indications. Posterolateral bone grafts were performed in accordance with standard,

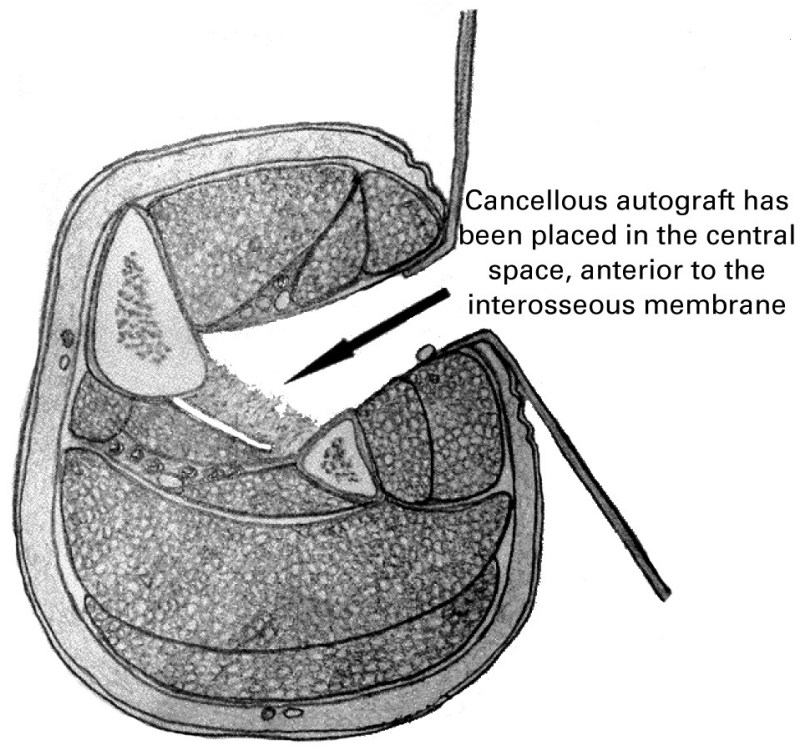

Fig. 2

Diagram of a cross-section through the mid-tibia, showing the interval for the approach and fibular decortication. An osteoperiosteal flap has been raised posteriorly off the lateral aspect of the tibia and the interosseous membrane has been detached from the fibula. This creates the central space for placement of the graft.

well-known techniques and for similar indications as central bone grafting. ${ }^{5}$

All patients were followed up until the fracture had united. Radiographic union was judged to have occurred in the presence of three bridging bony cortices crossing the fracture site on two orthogonal views. Some patients developed clear radiographic evidence of tibiofibular synostosis above and below their segmental deficit. If clinical healing was present, these patients were also judged to have achieved union. Clinical healing was defined as the ability of the patient to bear weight painlessly on the affected limb, and by a lack of pain when manual stress was placed across the site of nonunion by an examiner (SJM, WRS or resident physician under their direct supervision).

The records were reviewed for evidence of complications, including compartment syndrome, neurovascular injury, infection, problems with wound healing, failure of consolidation of the fracture, development of an equinus contracture of the ankle, malalignment, leg-length discrepancy, or the need for additional operations.

Central bone grafting: technique of the operation. The patient is placed supine. The involved leg and the ipsilateral anterior iliac crest are prepared and draped. After elevation of the limb, the tourniquet is inflated. Elastic bandage exsanguination is not used in previously infected cases because of the risk of dislodging emboli. ${ }^{6}$

A lateral incision is made just anterior to the fibula. The interval between the peroneal muscles and the extensor digitorum separating the anterior and lateral compartments is developed, taking care to protect the superficial peroneal 
Table I. Details of the patients with central bone grafting

\begin{tabular}{|c|c|c|c|c|c|c|c|c|c|c|c|c|}
\hline Patient & $\begin{array}{l}\text { Age } \\
\text { t(yrs) }\end{array}$ & Gender & rSide & $\begin{array}{l}\text { Location } \\
\text { in tibia }\end{array}$ & Grade & $\begin{array}{l}\text { Infection } \\
\text { history }\end{array}$ & $\begin{array}{l}\text { Segmental } \\
\text { bone loss } \\
(\mathrm{cm})\end{array}$ & $\begin{array}{l}\text { Time to } \\
\text { union (wks) }\end{array}$ & $\begin{array}{l}\text { Time after } \\
\text { initial injury } \\
\text { (mths) }\end{array}$ & $\begin{array}{l}\text { Number of } \\
\text { previous operations }\end{array}$ & $\begin{array}{l}\text { Previous bone } \\
\text { graft or flap } \\
\text { coverage }\end{array}$ & Complications ${ }^{*}$ \\
\hline 1 & 22 & $\mathrm{~F}$ & $\mathrm{R}$ & Distal & Closed & No & No & 10 & 6 & 1 & No & None \\
\hline 2 & 50 & $\mathrm{M}$ & $\mathrm{L}$ & Distal & IIIA & No & Yes, 4 & 20 & 2 & 2 & No & None \\
\hline 3 & 28 & $\mathrm{M}$ & $\mathrm{L}$ & Distal & IIIA & No & Yes, 5 & 18 & 3 & 2 & No & None \\
\hline 4 & 48 & $\mathrm{M}$ & $\mathrm{L}$ & Distal & $\mathrm{GSW}^{\dagger}$ & Yes & No & 24 & 36 & 6 & Bone graft & Equinus $>10^{\circ}$ \\
\hline 5 & 19 & $\mathrm{M}$ & $\mathrm{L}$ & Mid-shaft & IIIB & Yes & No & 10 & 6 & 4 & $\begin{array}{l}\text { Bone graft, } \\
\text { soleus }\end{array}$ & Equinus $>10^{\circ}$ \\
\hline 6 & 30 & $\mathrm{M}$ & $\mathrm{R}$ & Distal & IIIB & No & No & 16 & 22 & 3 & Rectus flap & $\begin{array}{l}\text { Intra-operative } \\
\text { anterior tibial } \\
\text { artery injury }\end{array}$ \\
\hline 7 & 44 & $\mathrm{M}$ & $\mathrm{L}$ & Distal & I & No & No & 20 & 11 & 1 & No & None \\
\hline 8 & 78 & $\mathrm{M}$ & $\mathrm{L}$ & $\begin{array}{l}\text { Prox }+ \\
\text { Distal }\end{array}$ & IIIC & No & No & 18 & 2.3 & 3 & No free flap & Pain at ICBG site \\
\hline 9 & 18 & $\mathrm{~F}$ & $\mathrm{R}$ & Proximal & IIIB & No & Yes, 4 & 15 & 7 & 2 & $\begin{array}{l}\text { Gastrocnemius } \\
\text { flap }\end{array}$ & None \\
\hline 10 & 49 & $\mathrm{M}$ & $\mathrm{L}$ & Proximal & IIIA & No & No & 16 & 7 & 2 & No & $\begin{array}{l}(+) \text { intra-operative } \\
\text { culture }\end{array}$ \\
\hline 11 & 35 & $\mathrm{M}$ & $\mathrm{L}$ & Mid-shaft & IIIA & No & No & 16 & 5 & 2 & No & None \\
\hline 12 & 47 & $\mathrm{~F}$ & $\mathrm{~L}$ & Mid-shaft & Closed & No & No & 13 & 9 & 2 & No & None \\
\hline 13 & 51 & $\mathrm{~F}$ & $\mathrm{R}$ & Distal & IIIB & No & Yes, 3 & 48 & 6 & 1 & Soleus flap & $\begin{array}{l}(+) \text { intra-operative } \\
\text { culture, flap } \\
\text { revision }\end{array}$ \\
\hline 14 & 14 & $\mathrm{M}$ & $\mathrm{R}$ & Distal & IIIB & No & No & 40 & 2.8 & 3 & Free flap & $\begin{array}{l}\text { (+) intra-operative } \\
\text { culture }\end{array}$ \\
\hline 15 & 23 & $\mathrm{~F}$ & $\mathrm{~L}$ & Distal & IIIA & No & Yes, 5 & 14 & 1.5 & 2 & No & None \\
\hline 16 & 59 & $\mathrm{M}$ & $\mathrm{L}$ & Distal & Closed & No & No & 22 & 12 & 2 & No & $\begin{array}{l}\text { (+) intra-operative } \\
\text { culture }\end{array}$ \\
\hline 17 & 27 & $\mathrm{M}$ & $\mathrm{R}$ & Mid-shaft & IIIA & No & Yes, 3.5 & 16 & 1.5 & 1 & No & None \\
\hline 18 & 33 & $\mathrm{M}$ & $\mathrm{R}$ & Mid-shaft & IIIA & No & Yes, 2.5 & 14 & 7 & 2 & No & None \\
\hline 19 & 36 & $\mathrm{M}$ & $\mathrm{R}$ & Mid-shaft & IIIB & No & Yes, 3 & 28 & 20 & 4 & $\begin{array}{l}\text { Bone graft, } \\
\text { soleus flap }\end{array}$ & None \\
\hline 20 & 39 & $M$ & $\mathrm{~L}$ & Distal & IIIA & No & Yes, 2 & 16 & 5 & 4 & No & None \\
\hline 21 & 30 & $\mathrm{~F}$ & $\mathrm{~L}$ & Distal & IIIA & Yes & Yes, 2 & 30 & 4 & 3 & No & $\begin{array}{l}\text { Equinus }>10^{\circ} \text {, } \\
\text { post-operative } \\
\text { infection, I\&D, } \\
\text { HWR after non- } \\
\text { union consolida- } \\
\text { tion }\end{array}$ \\
\hline 22 & 46 & $M$ & $\mathrm{R}$ & Distal & Closed & Yes & No & 16 & 36 & 2 & Bone graft & None \\
\hline 23 & 47 & $\mathrm{~F}$ & $\mathrm{~L}$ & Mid-shaft & IIIA & No & Yes, 5 & 16 & 8 & 2 & No & None \\
\hline 24 & 35 & $M$ & $\mathrm{R}$ & Distal & IIIB & Yes & No & 28 & 12 & 4 & Rectus flap & None \\
\hline
\end{tabular}

* ICBG, iliac crest bone graft; I\&D, incision and drainage; HWR, hardware removal

† GSW, gunshot wound

nerve. This exposes the anterior aspect of the fibula and the interosseous membrane.

A periosteal elevator is used to elevate the muscles and neurovascular bundle of the anterior compartment off the interosseous membrane, until the lateral aspect of the tibia is exposed proximal and distal to the nonunion. The periosteum of the tibia is then incised $2 \mathrm{~mm}$ or $3 \mathrm{~mm}$ anterior to the attachment of the interosseous membrane and elevated as an ostealperiosteal flap, allowing initial decortication of the bone. The ostealperiosteal flap and the interosseous membrane are detached in one layer from the tibia and retracted posteriorly (Fig. 1). Specimens of tissue from the site of nonunion are taken for culture.

Further aggressive decortication of the tibia proximal and distal to the fracture site is performed, with the site of nonunion left undisturbed. Fibrous tissue is debrided until bleeding is encountered. Vascular fibrous tissue helps stabilise the fracture, has osteogenic potential and may contribute to consolidation. ${ }^{7,8}$ The only indications for debridement of the site of nonunion are the presence of a sequestrum, malunion which requires surgical correction, or a synovialised pseudarthrosis. ${ }^{9}$ In such cases an adequate debridement is performed.

The medial aspect of the fibula is then decorticated with a gouge or burr and the attachment of the membrane is released. The development of these ostealperiosteal flaps creates a central space bordered by the tibia, interosseous membrane and periosteum, and the fibula, which together form a bed for placement of the graft (Fig. 2).

Cancellous bone graft is taken from the anterior iliac crest, which is osteotomised and then opened on a medial hinge in a 'trapdoor' fashion. Cancellous bone is harvested through the window. Usually between $25 \mathrm{~g}$ and $40 \mathrm{~g}$ can be removed from between the cortical tables of the ilium using 
Table II. Details of the patients with posterolateral bone grafting

\begin{tabular}{|c|c|c|c|c|c|c|c|c|c|c|c|c|}
\hline Patient & $\begin{array}{l}\text { Age } \\
\text { (yrs) }\end{array}$ & Gender & Side & $\begin{array}{l}\text { Location } \\
\text { in tibia }\end{array}$ & Grade & $\begin{array}{l}\text { Infection } \\
\text { history }\end{array}$ & $\begin{array}{l}\text { Segmental } \\
\text { bone loss }(\mathrm{cm})\end{array}$ & $\begin{array}{l}\text { Time to } \\
\text { union (wks) }\end{array}$ & $\begin{array}{l}\text { Time after } \\
\text { initial injury } \\
\text { (mths) }\end{array}$ & $\begin{array}{l}\text { Number of } \\
\text { previous operations }\end{array}$ & $\begin{array}{l}\text { Previous bone } \\
\text { graft or flap } \\
\text { coverage }\end{array}$ & Complications ${ }^{*}$ \\
\hline 1 & 23 & $\mathrm{M}$ & $\mathrm{L}$ & Mid-shaft & 1 & Yes & No & 20 & 25 & 3 & No & None \\
\hline 2 & 45 & $\mathrm{M}$ & $\mathrm{L}$ & Distal & II & Yes & No & 40 & 30 & 3 & Bone graft & Repeat PLBG \\
\hline 3 & 45 & $\mathrm{~F}$ & $\mathrm{R}$ & Mid-shaft & Closed & No & No & 20 & 8 & 2 & No & None \\
\hline 4 & 39 & $\mathrm{M}$ & $\mathrm{R}$ & Distal & IIIA & No & Yes, 5 & 24 & 30 & 3 & Bone graft & None \\
\hline 5 & 22 & $M$ & $\mathrm{R}$ & Distal & IIIA & No & No & 28 & 19 & 3 & No & $\begin{array}{l}\text { Equinus } 5^{\circ} \text { and } \\
\text { peroneal artery } \\
\text { laceration }\end{array}$ \\
\hline 6 & 57 & $\mathrm{M}$ & $\mathrm{L}$ & Distal & IIIB & Yes & No & 32 & 32 & 5 & Rectus flap & $\begin{array}{l}\text { Post-operative } \\
\text { infection and I\&D }\end{array}$ \\
\hline 7 & 47 & $\mathrm{M}$ & $\mathrm{L}$ & Distal & IIIA & No & Yes, 2.5 & 18 & 6 & 1 & No & None \\
\hline 8 & 41 & $\mathrm{M}$ & $\mathrm{R}$ & Proximal & II & No & No & 16 & 15 & 1 & No & None \\
\hline 9 & 35 & $\mathrm{M}$ & $\mathrm{L}$ & Distal & IIIA & No & Yes, 5 & $\mathrm{~N} / \mathrm{A}^{\dagger}$ & 6 & 2 & No & Lost to follow-up \\
\hline 10 & 32 & $M$ & $\mathrm{R}$ & Distal & IIIA & No & No & 44 & 11 & 2 & No & None \\
\hline 11 & 21 & $\mathrm{~F}$ & $\mathrm{~L}$ & Distal & IIIB & No & Yes, 5 & 40 & 14 & 3 & Free flap & None \\
\hline 12 & 31 & $\mathrm{M}$ & $\mathrm{L}$ & Distal & I & No & No & 28 & 12 & 1 & No & None \\
\hline 13 & 40 & $M$ & $\mathrm{R}$ & Mid-shaft & IIIA & Yes & No & 60 & 10 & 3 & No & None \\
\hline 14 & 33 & $\mathrm{~F}$ & $\mathrm{~L}$ & Proximal & IIIA & No & No & 42 & 23 & 3 & Bone graft & $\begin{array}{l}\text { Exchange } \\
\text { intramedullary } \\
\text { nailing }\end{array}$ \\
\hline 15 & 48 & $\mathrm{~F}$ & $\mathrm{R}$ & Distal & IIIA & Yes & Yes, 6 & $\mathrm{~N} / \mathrm{A}$ & 9 & 2 & No & $\begin{array}{l}\text { Below-knee } \\
\text { amputation }\end{array}$ \\
\hline 16 & 45 & $\mathrm{M}$ & $\mathrm{R}$ & Distal & IIIA & No & No & 16 & 10 & 1 & No & None \\
\hline 17 & 25 & $\mathrm{M}$ & $\mathrm{L}$ & Mid-shaft & IIIB & Yes & Yes, 3 & 20 & 19 & 4 & $\begin{array}{l}\text { Lateral flap, } \\
\text { bone } \\
\text { graft }\end{array}$ & $\begin{array}{l}3 \mathrm{~cm} \text { leg-length } \\
\text { discrepancy }\end{array}$ \\
\hline 18 & 54 & $\mathrm{M}$ & $\mathrm{L}$ & Proximal & IIIA & Yes & No & 40 & 16 & 2 & No & $\begin{array}{l}(+) \text { intra- } \\
\text { operative culture }\end{array}$ \\
\hline 19 & 56 & $\mathrm{M}$ & $\mathrm{R}$ & Mid-shaft & IIIA & Yes & No & 36 & 8 & 3 & No & Equinus $>10^{\circ}$ \\
\hline 20 & 20 & $\mathrm{M}$ & $\mathrm{L}$ & Mid-shaft & IIIB & Yes & Yes, 2 & 40 & 18 & 5 & Soleus flap & Required CBG \\
\hline
\end{tabular}

* PLBG, posterolateral bone graft; I\&D, incision and drainage; CBG, central bone grafting

$+\mathrm{N} / \mathrm{A}$, not available

a curette and gouge. The trapdoor is then closed and sutured back into place.

The cancellous graft is placed in the newly created central space between the tibia and the fibula. The volume of graft generally makes it impossible to close the fascia, so careful closure of the subcutaneous tissue and skin is necessary.

After grafting, stabilisation of the nonunion may be undertaken as appropriate using a plate or an external fixator. In one of our cases of central bone grafting a long-leg cast was the only method of immobilisation used. The limb is elevated and appropriate antibiotics are given for 48 hours following the procedure. Weight-bearing depends on the stability of the nonunion. All our patients were non-weightbearing until sound wound healing was achieved and then progressed according to the stability of the nonunion.

The differences between our technique and that described in the original paper by Rijnberg and van Linge ${ }^{2}$ include our preference for the supine instead of the lateral position. Rijnberg and van Linge ${ }^{2}$ removed all implants and used a plastercast to stabilise the limb after operation. If appropriate, it is nearly always possible to stabilise the nonunion with a plate through the described approach. We took bone graft from the anterior instead of the posterior aspect of the iliac crest, and Rijnberg and van Linge ${ }^{2}$ used corticocancellous strips of bone, whereas we used a 'trap- door' in the iliac crest to harvest purely cancellous bone. If there is an un-united fracture of the fibula at the level of the nonunion of the tibia, the fibular fracture must be stabilised for a tibiofibular synostosis to be effective.

\section{Results}

During the study period, 146 nonunions of the tibia were treated operatively at our institution, 24 by central (Table I), and 20 by posterolateral bone grafting (Table II), with or without mechanical stabilisation. All the nonunions were atrophic. Active infection was treated before any type of bone graft was placed in all cases by debridement of grossly infected tissue followed by six weeks of culture specific intravenous antibiotics. No patient in the central bone grafting group and only one in the posterolateral group was lost to follow-up.

The two groups were similar in terms of mean age, gender distribution, affected side, the mean number of previous operations and the location in the tibia. However, there were major differences. More patients in the posterolateral group (nine), had a history of infection than did those in the central group (five). In the central bone grafting group 11 had pre-operative bone loss, of a mean $3.5 \mathrm{~cm} \mathrm{(2} \mathrm{to} \mathrm{5),} \mathrm{and}$ seven posterolateral bone grafting patients had a mean loss of $4.0 \mathrm{~cm} \mathrm{(2} \mathrm{to} 6)$ of bone. One patient in the central group 
Table III. Comparison of the patients with central and posterolateral bone grafting and results

\begin{tabular}{|c|c|c|c|c|c|c|c|c|c|c|c|}
\hline $\begin{array}{l}\text { Group* } \\
\text { (range) }\end{array}$ & $\begin{array}{l}\text { Mean age } \\
\text { in yrs }\end{array}$ & Gender & Side & $\begin{array}{l}\text { Location } \\
\text { in tibia }\end{array}$ & $\begin{array}{l}\text { Grade of } \\
\text { initial } \\
\text { injury }\end{array}$ & $\begin{array}{l}\text { Infection } \\
\text { history }\end{array}$ & $\begin{array}{l}\text { Segmental } \\
\text { bone loss }\end{array}$ & $\begin{array}{l}\text { Mean time } \\
\text { to union } \\
\text { (wks) }\end{array}$ & $\begin{array}{l}\text { Time after } \\
\text { initial injury } \\
\text { (mths) }\end{array}$ & $\begin{array}{l}\text { Number of } \\
\text { previous } \\
\text { operations }\end{array}$ & Complications $^{\ddagger}$ \\
\hline \multirow[t]{6}{*}{$\mathrm{CBG}^{\ddagger}$} & $\begin{array}{l}37.8 \\
(18 \text { to } 78)\end{array}$ & $\mathrm{M}: 17$ & $\mathrm{R}: 10$ & Distal: 15 & IIIC: 1 & 5 patients & 11 patients & 20 (10 to 48$)$ & $9.6(1.5$ to 36$)$ & 2.5 (1 to 6$)$ & $4(+)$ intra-op culture \\
\hline & & & $\mathrm{L}: 14$ & $\begin{array}{l}\text { Mid-shaft: } \\
7\end{array}$ & IIIB: 7 & $\begin{array}{l}1 \text { also had bone } \\
\text { loss }>2 \mathrm{~cm}\end{array}$ & $\begin{array}{l}\text { mean: } 3.5 \\
\mathrm{~cm}\end{array}$ & & & & 3 equinus $>10^{\circ}$ \\
\hline & & $\mathrm{F}: 7$ & & $\begin{array}{l}\text { Proximal: } \\
3\end{array}$ & IIIA: 10 & & & & & & 1 pain at ICBG site. \\
\hline & & & & & II: 0 & & & & & & $\begin{array}{l}1 \text { anterior tibial artery } \\
\text { injury. }\end{array}$ \\
\hline & & & & & $\begin{array}{l}\text { I: } 1 \\
\text { Closed: } 4\end{array}$ & & & & & & $\begin{array}{l}1 \mathrm{I} \& \mathrm{D}, \mathrm{HWR} 2 \text { years } \\
\text { after non-union healing }\end{array}$ \\
\hline & & & & & GSW: 1 & & & & & & \\
\hline \multirow[t]{7}{*}{ PLBG } & $\begin{array}{l}38 \\
(20 \text { to } 57)\end{array}$ & M: 16 & $\mathrm{R}: 9$ & Distal: 11 & IIIC: 0 & 9 patients & 7 patients & $\begin{array}{l}31.3 \text { (16 to } \\
60)\end{array}$ & $16(6$ to 30$)$ & $2.6(1$ to 5$)$ & 2 repeat bone grafts \\
\hline & & $\mathrm{F}: 4$ & $\mathrm{~L}: 11$ & $\begin{array}{l}\text { Mid-shaft: } \\
6\end{array}$ & IIIB: 4 & $\begin{array}{l}3 \text { also had bone } \\
\text { loss }>2 \mathrm{~cm}\end{array}$ & mean: $4 \mathrm{~cm}$ & & & & 1 exchange nailing \\
\hline & & & & $\begin{array}{l}\text { Proximal: } \\
3\end{array}$ & IIIA: 11 & & & & & & $1 \mathrm{BKA}$ \\
\hline & & & & & II: 2 & & & & & & 2 equinus $>5^{\circ} \mathrm{deg}$ \\
\hline & & & & & I: 2 & & & & & & $\begin{array}{l}13 \mathrm{~cm} \text { leg-length } \\
\text { discrepancy }\end{array}$ \\
\hline & & & & & Closed: 1 & & & & & & $\begin{array}{l}1(+) \text { intra-operative } \\
\text { culture }\end{array}$ \\
\hline & & & & & GSW: 0 & & & & & & $\begin{array}{l}1 \text { post-operative acute } \\
\text { infection I\&D }\end{array}$ \\
\hline
\end{tabular}

* CBG, central bone graft; PLBG, posterolateral bone graft

t the number of central bone grafts in this chart adds up to 25 because one patient had both a proximal and distal nonunion in the same tibia. Both were bone grafted

‡ underlined complications are those that were necessary due to failure of bony healing after the bone graft; ICBG, iliac crest bone graft; HWR, hardware removal; BKA, below-knee amputation; I\&D, incision and drainage

had both an infection and bone loss, and the posterolateral group included three such patients.

The interval from the initial injury until bone grafting was longer in the posterolateral group (mean 16 months, 1.5 to 36 ) than in the central group (mean 9.6 months, 6 to 32). This difference is accounted for in part because four of the central bone grafting patients had bone grafting within three months because of loss of more than $3 \mathrm{~cm}$ of bone, which was thought to lead to an inevitable nonunion. ${ }^{10}$ One central bone grafting patient had a grade $3 \mathrm{C}$ open fracture of both the proximal and distal tibia. Both sites received a bone graft nine weeks after injury.

There were eight central bone grafting patients who had a previous flap cover associated with Gustilo-Anderson 3B or $3 \mathrm{C}$ fractures, but only four posterolateral patients had received this. The central bone grafting patients included one with a gunshot wound and four who initially had closed injuries, whereas all but one of those with posterolateral grafting had a primary injury that was open. In both groups four patients had undergone a bone grafting procedure elsewhere before the operation, for which they were included in this study.

All central bone grafting nonunions united, and none required further bone grafting. One patient (no 13) required revision of a soleus flap to a rectus free flap for soft-tissue breakdown. The incision for the central bone grafting was not involved and healed uneventfully. However, four posterolateral bone grafting patients had additional procedures because the bone failed to heal, with two undergoing subsequent further bone grafts. One had a further posterolateral bone grafting and another had a central bone grafting. This patient is not included in the central bone grafting data. Both of these secondary bone grafts resulted in union. A third patient had undergone a posterolateral bone grafting for a fracture of the proximal tibia which was treated initially with an intramedullary nail. There was no radiographic evidence of callus formation at 30 weeks and an exchange nailing procedure was carried out. The fracture was healed 12 weeks later. A final patient with a history of infection and a bone loss of $6 \mathrm{~cm}$ developed a post-operative infection and underwent incision and drainage, attempted bone transport, and ultimately a below-knee amputation (Table III).

Patients with central bone grafting achieved union at a mean of 20 weeks (10 to 48), whereas those in the posterolateral bone grafting group did so at mean of 31.3 weeks (16 to 60). No patient in either group developed compartment syndrome. All the wounds in the central bone grafting series healed uneventfully, but one posterolateral grafting patient required exploration of an actively infected wound, followed by intravenous antibiotic treatment, but eventually healed. All the central bone grafting patients and 


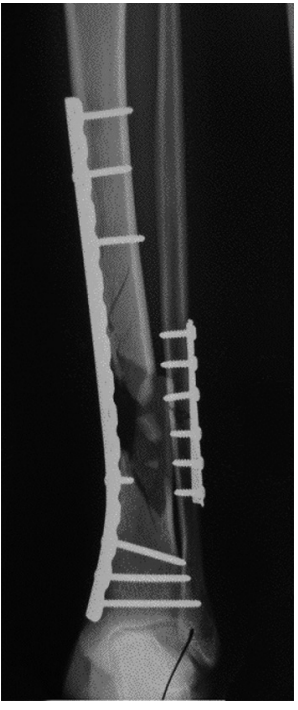

Fig. 3a

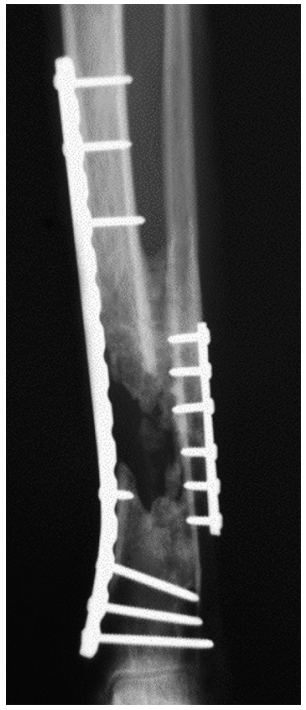

Fig. 3b
Radiographs of a 23-year-old male who sustained a grade $3 \mathrm{~A}$ open tibial fracture with bone loss in an industrial accident and a) was bone grafted acutely six weeks after his injury. b) Radiograph taken after six months showing the formation of a tibiofibular synostosis. He returned to full duty as a manual labourer approximately six months after the central bone grafting procedure.

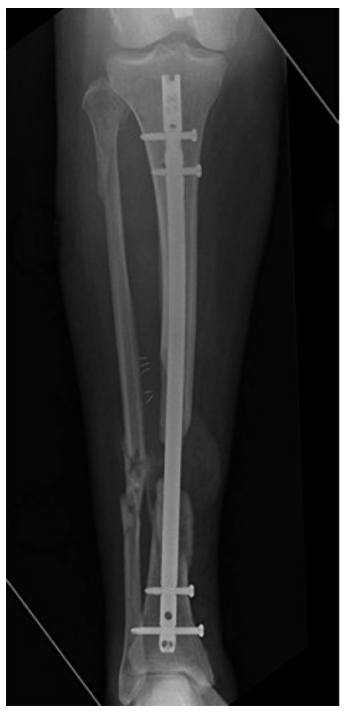

Fig. $4 a$

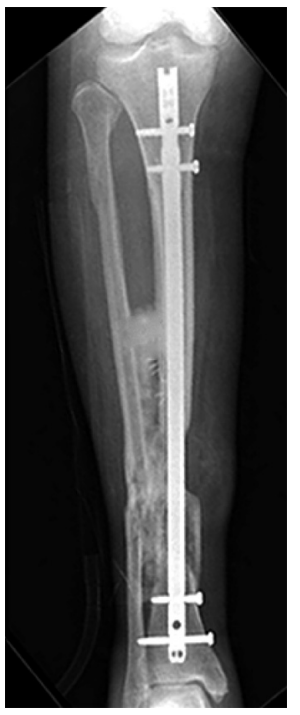

Fig. $4 b$
Radiographs of a 47-year-old female who sustained a grade 3 A open tibial fracture with bone loss in a motor vehicle collision. a) She initially underwent intramedullary nailing but eight months later had no evidence of callus formation and underwent central bone grafting. b) Radiograph at six months showing sound cross-union. She was able to bear weight painlessly and walk without a cane. all those with a posterolateral bone grafting, except the one who had an amputation, were able to return to full weightbearing without the need for a walking aid.

Five patients who had a central bone grafting and nine with a posterolateral grafting had a known infection when first seen. All were treated by debridement and administration of culture-specific intravenous antibiotics for six weeks before bone grafting. Their active infection had resolved before operation. The patients who presented with an infection had a more complicated course with either procedure. Of the nine posterolateral bone grafting patients, seven had an adverse post-operative event, as did three of five of those with a central bone grafting. However, 13 of these 14 patients went on to union.

Of the five central bone grafting patients who had been treated for infection, three had an equinus contracture of $>10^{\circ}$ when union was achieved; one of these patients (no 21) also developed a soft-tissue infection two years after union which resolved with incision and drainage, removal of the metalwork, and a course of intravenous antibiotics. The two patients with a central bone grafting and a history of infection had healed uneventfully. Neither had bone loss.

Only two of the nine posterolateral bone grafting patients with a history of infection had a smooth course to union after bone grafting, and neither had bone loss. One posterolateral bone grafting patient with a history of infection developed an equinus contracture $>10^{\circ}$, another had $3 \mathrm{~cm}$ of leg-length discrepancy at the end of treat- ment, and a third needed a debridement two weeks after operation for acute infection. A final posterolateral bone grafting patient had a positive intra-operative culture and subsequently received six weeks of intravenous antibiotics before healing.

Five patients in the series had quiescent infection, four with a central and one with a posterolateral bone graft. They were all treated with a course of culture-specific intravenous antibiotics for six weeks and resolved without further problems. One of the patients (no 13) had a longer mean time to healing of 32 weeks ( 16 to 48 ) than the overall central bone grafting group. The patient with a posterolateral bone grafting healed at 40 weeks.

Patients with uninfected bone loss did very well with either procedure. Four in the posterolateral bone grafting group and ten with a central bone grafting had bone loss between $2 \mathrm{~cm}$ and $5 \mathrm{~cm}$ and no history of infection (Figs 3 and 4). All healed uneventfully, except for one whose positive intra-operative culture required six weeks of intravenous antibiotics. This patient had the longest time to union at 48 weeks.

All four patients who had both bone loss and a history of infection had adverse events, as noted earlier.

Vascular complications. There was one intra-operative neurovascular injury in the central bone grafting group and one in the posterolateral bone grafting group. The anterior tibial artery was injured in the central bone grafting patient when the vessel was encased in fibrous nonunion tissue. A primary repair of the injury was performed intra- 
operatively and the bone grafting procedure continued with a successful result. A peroneal artery was injured in a posterolateral bone grafting case and repaired successfully.

One patient with a central bone grafting complained of constant pain at the site of bone harvest from the iliac crest.

\section{Discussion}

Central bone grafting is a safe and effective method of treating nonunion of the tibia which is not amenable to intramedullary nailing. Compared with a group of patients who underwent posterolateral bone grafting, the central bone grafting patients healed faster, required fewer further operations, and ultimately achieved a similar rate of union. The results of the two procedures are comparable. In these challenging cases, circumstances such as previously placed skin grafts or flaps, or known damage to an arterial structure would favour one approach over the other. The incision is in a different location, and different anatomy is encountered, giving the flexibility to choose either approach based on the requirements of a given case.

Nonunion of a tibial shaft fracture is disabling and may threaten the viability of the limb. ${ }^{11}$ Treatment must be based on sound principles of stable fixation, control of infection (if present) and provision of an environment conducive to bone healing. ${ }^{12}$ Hypertrophic nonunion can be treated by mechanical stabilisation without grafting. Most aseptic nonunions of the tibia without bone loss can be managed by reamed intramedullary nailing, either by exchange or after discontinuation of another treatment, with excellent results. ${ }^{10,13-15}$ Bone transport, posterolateral bone grafting, and a graft of vascularised rib or fibula have been used in difficult cases, including those associated with bone loss or a history of infection. ${ }^{16}$ However, bone transport is a difficult technique which may present with various difficulties and complications. ${ }^{17-21}$

The use of vascularised autograft is a successful operation in selected cases, but microsurgical facilities are not universally available. The morbidity at the donor site is not trivial, and although the vascularised grafts may hypertrophy with time, there is a high incidence of fatigue fracture. $^{22,23} \mathrm{~A}$ history of local sepsis at the site of nonunion is associated with a high rate of failure. ${ }^{24,25}$

Our results have shown that bone defects up to $5 \mathrm{~cm}$ without previous infection can be reliably treated by central or posterolateral bone grafting. Although a somewhat more complex clinical course may be expected, patients with infection whose debridement does not produce a large bone gap $(>2 \mathrm{~cm})$ can reliably expect to achieve union. Patients who present with both significant bone loss and a history of infection are the most challenging. All four such patients in our series had an adverse event. Although a central or posterolateral bone grafting procedure can be successful in these cases, ${ }^{2,5,26,27}$ significant bone loss combined with a history of infection poses a complex problem, and the rigours of bone transport may offer a more reliable solution.
Experience with both central and posterolateral bone grafts has led us to conclude that supine positioning and a central bone graft is easier than the posterolateral bone graft if conditions are such that either strategy would be appropriate and has a lower risk of neurovascular injury. The limitations of this study are that it was a retrospective comparison review with a relatively small number of heterogeneous patients. However, our results, and those of Rijnberg and van Linge ${ }^{2}$ have shown that central bone grafting can be safely used to achieve bony union of ununited tibial fractures and is a useful tool for treating selected patients.

No benefits in any form have been received or will be received from a commercial party related directly or indirectly to the subject of this article.

\section{References}

1. Wiss DA, Stetson WB. Tibial nonunion: treatment alternatives. J Am Acad Orthop Surg 1996;4:249-57.

2. Rijnberg WJ, van Linge B. Central grafting for persistent nonunion of the tibia: a lateral approach to the tibia, creating a central compartment. J Bone Joint Surg $[\mathrm{Br}]$ 1993;75-B:926-31.

3. Gustilo RB, Anderson JT. Prevention of infection in the treatment of one thousand and twenty-five open fractures of the long bones: retrospective and prospective analysis. J Bone Joint Surg [Am] 1976;58-A:453-8.

4. Gustilo RB, Mendoza RM, Williams DN. Problems in the management of type III (severe) open fractures: a new classification of type III open fractures. J Trauma 1984;24:742-6.

5. Harmon PH. A simplified surgical approach to the posterior tibia for bone grafting and fibular transference. J Bone Joint Surg 1945;27:496-8.

6. Austin M. The Esmarch bandage and pulmonary embolism. J Bone Joint Surg [Br] 1963;45-B:384-5

7. Nicoll EA. Fractures of the tibial shaft: a survey of 705 cases. J Bone Joint Surg [Br] 1964;46-B:373-87.

8. Phemister DB. Treatment of ununited fractures by onlay bone grafts without screw or tie fixation and without breaking down of the fibrous union. J Bone Joint Surg 1947;29:946-60.

9. Johnson KD. Management of malunion and nonunion of the tibia. Orthop Clin North Am 1987;18:157-71

10. Court-Brown CM, Keating JF, Christie J, McQueen MM. Exchange intramedullary nailing: its use in aseptic tibial nonunion. J Bone Joint Surg [Br] 1995;77B:407-11.

11. Lerner RK, Esterhai JL, Polomano RC, Cheatle MD, Heppenstall RB. Quality of assessment of patients with posttraumatic fracture nonunion, chronic refractory osteomyelitis and lower-extremity amputation. Clin Orthop 1993;295:28-36.

12. Babhulkar S, Pande K, Babhulkar S. Nonunion of the diaphysis of long bones. Clin Orthop 2005;431:50-6.

13. Wu CC, Shih CH, Chen WJ, Tai CL. High success rate with exchange nailing to treat a tibial shaft aseptic nonunion. J Orthop Trauma 1999;13:33-8.

14. Templeman D, Thomas $\mathbf{M}$, Varecka T, Kyle R. Exchange reamed intramedullary nailing for delayed union and nonunion of the tibia. Clin Orthop 1995;315:169-75.

15. Zelle BA, Gruen GS, Klatt B, et al. Exchange reamed nailing for aseptic nonunion of the tibia. J Trauma 2004;57:1053-9.

16. Patzakis MJ, Zalavras CG. Chronic posttraumatic osteomyelitis and infected nonunion of the tibia: current management concepts. J Am Acad Orthop Surg 2005; 13:417-27.

17. Phieffer LS, Goulet JA. Delayed unions of the tibia. J Bone Joint Surg [Am] 2006;88-A:206-16.

18. Paley D. Problems, obstacles and complications of limb lengthening by the llizarov technique. Clin Orthop 1990;250:81-104.

19. Marsh DR, Shah S, Elliot J, Kurdy N. The llizarov method in nonunion, malunion and infection of fractures. J Bone Joint Surg [Br] 1997;79-B:273-9.

20. Sen C, Eralp L, Gunes T, et al. An alternative method for the treatment of nonunion of the tibia with bone loss. J Bone Joint Surg [Br] 2006;88-B:783-9. 
21. El-Rosasy MA. Acute shortening and re-lengthening in the management of bone and soft-tissue in complicated fractures of the tibia. J Bone Joint Surg [Br] 2007;89-B:80-8.

22. Jain AK, Sinha S. Infected nonunion of the long bones. Clin Orthop 2005;431:57-65.

23. Vail TP, Urbaniak JR. Donor-site morbidity with use of vascularized autogenous fibular grafts. J Bone Joint Surg [Am] 1996;78-A:204-11.

24. Weiland AJ, Moore JM, Daniel RK. The efficacy of free tissue transfer in the treatment of osteomyelitis. J Bone Joint Surg [Am] 1984;66-A:181-93.
25. Green SA, Jackson JM, Wall DM, et al. Management of segmental defects by Ilizarov intercalary bone transport method. Clin Orthop 1992;280:136-41.

26. Reckling FW, Waters $\mathbf{C H}$. Treatment of nonunions of fractures of the tibial diaphysis by posterolateral cortical cancellous-bone grafting. J Bone Joint Surg [Am] 1980;62-A:936-41.

27. Simon JP, Hoogmartens $\mathbf{M}$. The value of posterolateral bone grafting for nonunion of the tibia. Acta Orthop Belg 1984;50:557-64. 